\title{
2006-379: BRINGING STUDENT INNOVATIONS TO MARKET: A HINMAN \\ CEOS SUCCESS STORY
}

\section{Anik Singal, Affiliate Classroom, Inc.}

Mr. Singal is a 2005 graduate of the University of Maryland, College Park, earning a B.S. in Finance. He is an alumnus of the Hinman CEOs Program and was awarded the Program's "Entrepreneur of Year" in 2004-2005. He is the founder and president of Affiliate Classroom, Inc. Mr. Singal is a recognized leader in affiliate marketing.

\section{David Barbe, University of Maryland-College Park}

Dr. Barbe is the Executive Director of the Maryland Technology Enterprise Institute, Professor of Electrical and Computer Engineering, and Faculty Director of the Hinman CEOs Program at the University of Maryland, College Park. He received his B.S. and M.S. from West Virginia University and the Ph.D. from The Johns Hopkins University in Electrical Engineering. He is a Fellow of the IEEE. His publications focus on electronics technology and technology entrepreneurship. Dr. Barbe received the ASEE Entrepreneurship Division Outstanding Entrepreneurship Education Award in June 2003.

\section{James Green, University of Maryland-College Park}

Mr. Green is the Associate Director of the Hinman CEOs Program at the University of Maryland, College Park. He manages the Program's operations, coaches students in new venture creation, and instructs classes in technology entrepreneurship at the undergraduate and graduate level. Mr. Green earned a B.S. in Industrial Engineering from the Georgia Institute of Technology, a M.S. in Technology Management from the University of Maryland University College, and an M.B.A. from the Ross School of Business at the University of Michigan. He is experienced as a founder, manager, and advisor to start-ups in the education, energy, and software industries.

\section{Karen Thornton, University of Maryland-College Park}

Ms. Thornton is the Program Director of the Hinman CEOs Program and the Associate Director of Business Development for MTECH Ventures at the University of Maryland, College Park. She received a B.M. and M.M. in music performance from Florida State University and an M.B.A. from the University of Maryland. She managed her own career as a performing musician for 25 years and taught at Towson University and Jacksonville University. Ms. Thornton was a Fulbright Scholar. 


\title{
"Bringing Student Innovations to Market: \\ A Hinman CEOs Success Story" \\ James V. Green, Anik Singal, David F. Barbe, and Karen S. Thornton University of Maryland, College Park
}

\begin{abstract}
This paper discusses a study of the challenges and opportunities navigated by Anik Singal, a technology entrepreneur, during his senior year with the University of Maryland's Hinman CEOs Program. The paper examines the process and explores the trials and successes of how this finance major paired university resources with his entrepreneurial mindset to launch a successful Company. With his first-hand account of the key success factors, this study may serve as a model for building new entrepreneurship programs and as a tool to enhance existing entrepreneurship offerings.
\end{abstract}




\section{Introduction}

This paper discusses a study of the challenges and opportunities navigated by Anik Singal, a technology entrepreneur, during his senior year with the University of Maryland's Hinman CEOs Program. This paper examines the process and explores the trials and successes of how this finance major paired university resources with his entrepreneurial mindset to launch a successful Company. With his first-hand account of the key success factors, this study may also serve as a model for building new entrepreneurship programs and as a tool to enhance existing entrepreneurship offerings.

\section{The Hinman CEOs Program}

As the nation's first living-learning entrepreneurship program, the Hinman CEOs Program is a groundbreaking program placing entrepreneurially-minded undergraduate students from all academic disciplines in a unique community to explore new ventures. The mission of Hinman CEOs is to foster an entrepreneurial spirit, create a sense of community and cooperation, and positively impact the way that students see their career opportunities. Living and learning with other aspiring and practicing student entrepreneurs, enjoying ready access to mentoring and coaching from experienced advisors and instructors, and gaining the skills to actually start companies combine to foster a rich entrepreneurial experience.

\section{Affiliate Classroom}

Anik Singal is the founder and president of Affiliate Classroom, Inc., a leader in the affiliate training industry specializing in training entrepreneurs on increasing their online revenues through affiliate marketing. The Company is focusing on bringing together reputable internet merchants and webmasters who can successfully promote their products through a revenuesharing agreement. Customers join through a $\$ 30$ monthly subscription fee. In addition, Affiliate Classroom is preparing signature technology for merchants to use to allow them to effectively interact with and train their own webmasters. Affiliate Classroom, founded in 2005, is currently serving a customer base measured in tens of thousands.

At 19 years old, Anik Singal launched his first internet business in 2002, with a business model based in affiliate marketing. Within six months, he earned over $\$ 10,000$. In fall 2004, Anik Singal was accepted into the Hinman CEOs Program with hopes of bringing his newest innovation to market before graduation. By diving into the entrepreneurial community and embracing all facets of the education, networking, and mentoring components of the Hinman CEOs Program, his concept is now a reality one year later with an increasing number of employees and annual revenues measured in millions of dollars. 


\section{Literature Review}

Interest is growing in the processes by which individuals, organizations, and entrepreneurs learn (Senge, 1990). Block and Stumpf (1992), drawing on the work of Cooper (1982) and House (1982), have focused on the unique learning needs of entrepreneurs. Slevin and Colvin (1992) built on the research of Senge (1990) to evaluate team learning and team development in entrepreneurial environments. Guth, Kumaraswamy, and McErlean (1991) focused specifically on the relevance of models for experiential learning. Others have examined the area of learning from failure (Brehmer, 1980; Levitt and March, 1988; Sterman, 1989). As Day (1992, p. 137) emphasizes, "all organizations must be able to learn if they are to move into new businesses. In fact, virtually every aspect of organizational learning has relevance either directly or indirectly for entrepreneurial management." This point is reiterated in the research on organizational competencies and learning in new ventures (Leitch and Harrison, 1993).

Fundamental questions are what key characteristics undergraduate entrepreneurs should develop and by what means should the characteristics be fostered. This is tightly tied to learning models. Past research has identified the contributions of prior knowledge, creativity, and cognitive mechanisms to entrepreneurial learning, development, and performance. Ward (2004) emphasized that the ability to identify and act on opportunity is strongly influenced by the way individuals process and use knowledge. Baron (1998) and Mitchell, Smith, Seawright, and Morse (2000) theorized that select individuals recognize opportunities, where others may be based on personal differences in cognitive processing. In all of these areas, it is critical to consider that learning is the source of how knowledge asymmetries evolve.

Improved understanding of new learning models and programs to build entrepreneurial traits and skills within undergraduates interested in new ventures is closely aligned with the psychological characteristics of the students. Vesper and Gartner (1997) demonstrated the positive impact that university entrepreneurship programs have on students, the university, and the community. Public symposia, student consulting projects, and company spin-offs are examples of high value activities.

Areas influencing entrepreneurial successes have been found to include founder characteristics, firm attributes, business practices, and human resource management practices. Founder characteristics are widely believed to influence the cultures and behaviors of the firm (Mullins, 1996). Firm attributes of specific value include a growth-oriented vision and a commitment to growth. Along with firm attributes, business practices facilitating unique value creation and product superiority support rapid growth (Kim and Mauborgne, 1997). Within the final category of human resource management practices, the ability to attract and retain skilled and capable employees increases the probability that a firm will foster a growth-oriented strategy (Rich, 1999). 


\section{Methodology}

This paper discusses an empirically based analysis intended to advance the understanding of the entrepreneurial phenomenon in undergraduate students. This qualitative study focuses on a single case in the University of Maryland's Hinman CEOs Program during the 2004-2005 academic year. Anik Singal's experiences in the Hinman CEOs Program were examined throughout his one year in the Program. Data collected via interviews and working sessions throughout the year are included in this data set. Interviews in the fall of 2005, approximately six months after his graduation from the University of Maryland, were also included in the study.

The methodology is based on a two-stage process built upon the literature review. The initial stage was to evaluate Anik and Affiliate Classroom using Barringer, Jones, and Neubaum's (2005) characteristics of rapid-growth firms. These characteristics are segmented into founder characteristics, firm attributes, business practices, and human resource management practices. The second stage was to identify unique characteristics relevant to undergraduate student entrepreneurs in universities based on Anik's comments, reflections, and perspectives. The objective of this methodology was to develop a set of suggestions for programs and activities for universities to foster desired characteristics and behaviors of undergraduate entrepreneurs.

The findings for the singular case of Anik Singal's experiences were then compared to findings of critical success factors from the 90 undergraduate students of the Hinman CEOs Program. Using a qualitative approach through an online survey and one-to-one 30 minute interviews:

- $91.7 \%$ stated their "knowledge base has improved due to the Hinman CEOs Program."

- $86.3 \%$ stated their "network of individuals available and willing to assist me in starting and managing a new venture has improved due to the Hinman CEOs Program."

- $77.8 \%$ stated their "confidence to start and manage a new venture has improved due to the Hinman CEOs Program."

Value is further demonstrated from Program participants' satisfaction with the Program's ability to foster innovation, motivate growth strategies, and manage resources effectively. Within the survey, $94.4 \%$ of students stated that they "would recommend the Hinman CEOs Program to other students interested in an entrepreneurial experience."

\section{Discussion of Results}

The experiences of Anik are discussed in turn for founder characteristics, firm attributes, business practices, and human resource management. A table of the comparisons and contrasts initiates each of the four sections. Findings of this analysis are displayed in the left hand column in order of their influence on each section. For example, education is identified as the most important component of the founder characteristics. In the right hand column are the prioritized components of Barringer, Jones, and Neubaum's (2005) study. 


\subsection{Founder characteristics}

While our findings paralleled prior research in the significant positive influences of education and industry experience, three further characteristics emerged in this study. These are the founder's social capital, their passion for the new venture, and their personal confidence.

Table 1. Comparisons and contrasts of founder characteristics

\begin{tabular}{|c|c|}
\hline Our Findings & Literature Review \\
\hline Education & Education \\
\hline Industry experience & Industry experience \\
\hline *Social capital & Entrepreneurial experience \\
\hline *Passion & Founding team \\
\hline *Confidence & \\
\hline
\end{tabular}

* Emerging critical success factors from the Hinman CEOs program

\subsubsection{Education}

Anik credits his education as positively influencing the development of his entrepreneurial skills and abilities. This supports arguments of Sapienza and Grimm (1997) that awareness, creativity, quantitative abilities, and communication skills are enhanced through college education. As a finance major, Anik further credits his college education to a more intensive level of knowledge in finance and accounting.

Beyond his coursework, Anik was also a member of the Hinman CEOs Program. Students and alumni of Hinman CEOs share that their career ambitions and choices are highly impacted by the Hinman CEOs community. Living and learning with aspiring and practicing student entrepreneurs, enjoying ready access to mentoring and coaching, and gaining the skills to actually start companies have shaped their lives (Barbe, Green, and Thornton, 2005).

\subsubsection{Industry experience}

Anik's industry experience in affiliate marketing heavily influenced his ability to successfully launch and grow Affiliate Classroom. Prior to launching the Company, Anik spent two years as an affiliate in this industry. This served as the foundation for understanding the needs and wants of his future customers. His success supports research finding that entrepreneurs with experience in the same industry as their new venture will have a better understanding of the key success factors for that industry (MacMillan and Day, 1987). Furthermore, Barringer, Jones, and Neubaum (2005) found that entrepreneurs with prior industry experience occurred in 76 percent of the rapid-growth firms in their sample. Industry experience has provided Anik with not only valuable customer knowledge, but an intimacy with the challenges and opportunities in affiliate marketing and the network critical to capitalizing on opportunities. 


\title{
4.1.3. Social capital
}

It was critical for Anik to develop social and professional networks to manage his resources efficiently. This parallels the work of Liao and Welsch (2005) in the importance of social capital to technology entrepreneurs. From finding a low-cost, high quality website designer to securing a developer to build the core software product of the Company, social capital played a fundamental role.

The Hinman CEOs Program played a significant role as Anik lived alongside the community of 90 undergraduate aspiring and active entrepreneurs. With friends and teammates living together, cross disciplinary teams develop naturally as students' skill sets mix and match to develop and execute the next great idea. The lectures and weekly speaker series provide wonderful networking opportunities. In this environment, students gain confidence in their abilities to take the leap to launch a company and they benefit from one others' successes and challenges. The community is further supported with on-site mentoring and coaching by the directors of the Program.

\subsubsection{Passion}

Anik's passion for entrepreneurship and for Affiliate Classroom is one of his most critical success factors.

"Working for someone was never really something that I've considered since my sophomore year of college. The thrill for me is in the chase and managing the whole show. I could never do this at my age in a big company. And life is too short to wait your turn in the bureaucracy."

\section{Anik Singal}

While the passion for an industry is helpful to inspire the long hours and required, sustainable commitment, Anik's passion is also very high for entrepreneurship in and of itself.

"I found affiliate marketing as an interesting and low-cost niche to enter. But working for myself was the end goal."

\author{
Anik Singal
}

\subsubsection{Confidence level}

For an undergraduate university student, the decision to be an entrepreneur requires a confidence that is resilient and resolute. Anik says his parents viewed entrepreneurship as a synonym for unemployed. They did not initially see ignoring high paying jobs with benefits at established, respected firms in lieu of starting a new venture as a smart choice. Particularly for a young person, going against the norm of peers, the university, and even family are difficult decisions. Anik leveraged this risk by investing as much time as possible into his entrepreneurial vision before graduation. In this way, he was able to begin generating revenues as a student, prove to friends and family that his vision was plausible, and foster his own confidence that he could build a livelihood for himself as an entrepreneur. 
Anik's confidence was dealt a blow at the University of Maryland \$50K Business Plan Competition in May 2005. While his third place finish in the undergraduate category may be viewed as a respectable showing, it was a crushing loss in his eyes. With only weeks until graduation, a judging panel comprised of seasoned entrepreneurs and venture capitalists were unimpressed with Affiliate Classroom. They shared that they had seen "website builders" before, and that it did not work then and would not work now. The judges' opinions that there was no intellectual property to patent further drove the judges to place Affiliate Classroom last in the final field of three. This testing of Anik's vision and confidence resulted in his reexamination of his product strategy and an overhaul of his core product offering. Within three months of the competition, Affiliate Classroom was earning \$50,000 in monthly revenues and growing at $40 \%$ monthly.

\subsubsection{Entrepreneurial experience}

While Singer (2005) credits prior entrepreneurial experience as one of the most consistent predictors of future entrepreneurial performance, Anik is proving that this is not mandatory. Undergraduate students are typically limited in their entrepreneurial experiences. Internships with new ventures may enhance their collegiate experience. But Affiliate Classroom was Anik's first exposure to entrepreneurship as an employee or founder. While the complexity was a challenge, he leveraged his resources and network to find answers and solve problems.

\subsubsection{Founding team}

The literature suggests that larger teams bring the talent, resources, and social capital at a greater rate than a sole entrepreneur (Barkman, 1994). Fesser and Willard (1990) further emphasize that the psychological support from cofounders is an important factor for new venturing. In cases where a founder can derive the benefits of talent, resources, social capital, and psychological support informally from faculty and programs, Anik has demonstrated solopreneuring can work.

Anik successfully developed and launched the firm as a solopreneur, albeit not as a lone wolf. The benefits of more talent, contacts, and resources were derived from relationships within the Hinman CEOs Program. Through weekly meetings with the associate director of the Program, Anik benefited from a pseudo co-founder acting in a business development role, a financial analyst position, a marketer, and a host of other roles. Psychological support was provided in the form of mentoring and coaching with encouraging, albeit sincere and direct, support.

\subsection{Firm attributes}

Anik aspires to build a nationally recognized firm in affiliate marketing, if not a global powerhouse. While the vision was a bold one for a 21 year-old undergraduate student, success of other Hinman CEOs and alumni provided precedence and support. This vision and commitment to growth parallels the literature review. The importance of planning is evident with Anik. Contrary to the literature, the relationships with other firms have not played a role in Affiliate Classroom's growth thus far. 
Table 2. Comparisons and contrasts of firm attributes

\begin{tabular}{|c|c|}
\hline Our Findings & Literature Review \\
\hline Vision for growth & Vision for growth \\
\hline Commitment to growth & Commitment to growth \\
\hline *Planning & Relationships with other firms \\
\hline
\end{tabular}

* Emerging critical success factors from the Hinman CEOs program

\subsubsection{Growth-oriented vision and mission}

A growth-oriented commitment articulated through a vision, mission, or values statement crystallizes the importance of growth to a firm and promotes a decision-making approach in tune with growth (Kim and Mauborgne, 1997).

In an industry characterized by infomercial-like websites and questionable professional credibility, one of the first priorities for Anik was to develop the firm's mission statement. This mission statement is "to be the premiere affiliate marketing training center in the world by placing our students (customers) first and fostering a community of collaborative education and mutual success." The vision is "to serve as a primary communication intermediary between reputable merchants and their affiliates." This established the personal vision of Anik. This also placed him in good company with nearly 60 percent of rapid-growth firms putting their growth vision in writing, with only 15 percent of slow-growth firms doing so (Doorley and Donovan, 1999).

The importance of growth through providing unique customer value is established in the vision and mission of Affiliate Classroom. The vision and mission also set the stage for what is important to growth in Anik's approach. A decision-making philosophy is also established in that placing the customer first is the chosen path for Affiliate Classroom's growth and prosperity.

\subsubsection{Commitment to growth}

For growth to exist, it must be cultivated through consistent, deliberate choices of founders (Kolvereid, 1992). The commitment to growth founded in the mission and vision of Affiliate Classroom is supported throughout the activities and personnel of the organization. Growth is articulated as an objective and performance measures are in place to assess and analyze growth towards goals.

The goal setting process is a concentrated effort receiving recurring attention of Anik. Goals are seen as the means for him and his team to commit to growth. In this way, accountability is introduced and managed to foster a collective commitment to growth. 


\subsubsection{Planning}

Constant attention to assessing the market, analyzing the competition, and improving the product offerings and customer service are highly correlated to new venture success (Duchesneau and Gartner, 1990). Through conscientious planning, Anik is effectively achieving his growth objectives. Planning provides a forum for Anik to outline his strategy and manage growth. While the plans may change and immediate direct utility is limited at times, the exercise of thinking through the planning improves his ability to react, realign resources and strategy, and flourish in this rapidly changing market.

\subsubsection{Relationships with other firms}

While Braggs (1999) found that interorganizational relationships such as joint ventures and alliances can accelerate growth, Anik has effectively managed growth without such affiliations. Through informal relationship derived from his social capital, Affiliate Classroom has leveraged its resources, managerial talents, and intellectual capabilities. Building expertise and reputation through conference participation and networking is a key future strategy for the firm. Alliances are also an important component of the firm's growth strategy in future years. Interorganizational relationships are not, however, an initial key success factor thus far for Affiliate Classroom.

\subsection{Business practices}

Anik's business practices parallel the literature review with slight exception in the reliance on product superiority in favor of innovation.

Table 3. Comparisons and contrasts of business practices

\begin{tabular}{|c|c|}
\hline Our Findings & Literature Review \\
\hline Unique value & Unique value \\
\hline Customer knowledge & Customer knowledge \\
\hline *Innovation & Product superiority \\
\hline
\end{tabular}

* Emerging critical success factors from the Hinman CEOs program

\subsubsection{Creating unique value for customers}

Firms can achieve and maintain rapid growth by delivering unique value through new solutions with enhanced capabilities, more affordability, or greater conveniences (Kim and Mauborgne, 1997). Affiliate Classroom is dedicated to supporting and helping their customers achieve success. This is evidenced with a 14 day trial offered for $\$ 1$ and commitment to customer service.

By serving aspiring and active online affiliates with a flexible, comprehensive training platform, Affiliate Classroom is exponentially improving the effectiveness of their customers in marketing products and services online. These affiliates are experiencing larger profits in shorter timelines 
and attributing this to their learning in the Affiliate Classroom. The completeness of the Affiliate Classroom and the step-by-step approach to learning is a true differentiator in affiliate training.

\subsubsection{Customer knowledge}

Anik is focused on gaining the trust and confidence of customers by providing them with excellence in service and value in the product. Through his years as an affiliate marketer, Anik sees himself as serving peers working in an environment with limited training opportunities and no one to mentor them in their professional development.

"I learned about affiliate marketing through many nights on discussion boards and websites. It took months of piecing together bits of knowledge to make any sense of what it takes to succeed online. I also spent a ton of money on worthless eBooks and related material. I wish Affiliate Classroom would have been around when I started."

Anik Singal

\subsubsection{Innovation}

The growth of firms is stimulated by pairing innovation (Deeds, 1999) with research and development (Chakrabarti, 1990). By focusing on serving all levels of affiliate marketers with a step by step coaching, project management, and tracking system, Affiliate Classroom has a simple goal. That is to make the entire process simple, easy, and fast for its customers.

The Affiliate Classroom has developed a signature training system to allow customers to receive step by step training and never be overwhelmed with what to do next. This training system has taken Anik over a year to develop. Top affiliates from around the world were personally interviewed on the system they used to develop their own successes. After reviewing the interviews and success of many high performing affiliates, Affiliate Classroom was able to finalize their initial training program to reflect the success of hundreds of affiliates.

The innovation of Affiliate Classroom is in providing for the first time in the market a comprehensive training platform customizable to each student's needs. There were no comparable offerings when Affiliate Classroom was launched and there have been none sense. The market continues to be too small for major online competitors such as Google, Yahoo!, or Commission Junction to serve, yet too big for most start-ups to adequately address. Affiliate Classroom enjoys a first mover advantage and is now recognized as a leader in affiliate marketing.

\subsubsection{Product superiority}

Product superiority is often referenced as a contributor to firm growth (Harrison and Taylor, 1997; Roure and Keeley, 1990). Easing market entry and establishing a basis of differentiation are typical benefits of product superiority. 
While Affiliate Classroom is offering a differentiated product, they believe in the motto that "good enough is good enough" in the rapidly evolving affiliate marketing field.

"There are a ton of things that we could do better. I have a long list of new features for my developers to integrate. I'm seeing new things pop up in other industries that we could surely use for our customers. But while we are not as great as we could be, we offer a great product at a great price. This fills the gaps and brings in the revenues needed to continue building and to keep innovating."

Anik Singal

\subsection{Human resource management}

Financial incentives play a large role in Affiliate Classroom's compensation strategy. Selective hiring has also shaped the success of the Company.

Table 4. Comparisons and contrasts of business practices

\begin{tabular}{|c|c|}
\hline Our Findings & Literature Review \\
\hline Financial incentives & Financial incentives \\
\hline *Selective hiring & Training \\
\hline
\end{tabular}

* Emerging critical success factors from the Hinman CEOs program

\subsubsection{Financial incentives}

Performance-based incentives are proven to attract (Zenger, 1992), motivate (Landau and Leventhal, 1976), retain (Rich, 1999), and increase the productivity of employees (Weitzman and Kruse, 1990). A significant share of the compensation at Affiliate Classroom is structured as bonuses, thereby tying a performance-based expectation to the costs of salary. The bonuses are based on both Company performance in terms of revenues and profitability as well as individual performance. Stock options are not presently used by the Company. This may be revisited later in the Company's growth period as the valuation can be better estimated and understood.

\subsubsection{Selective hiring}

PricewaterhouseCooper's Trendsetter Barometer (2000) identified staffing as the number one concern of CEOs of rapid-growth firms. Anik adheres to the fact that attracting and retaining skilled and capable employees are critical for firms to pursue a growth-oriented strategy (Rich, 1999).

Anik's approach to hiring is to fill the right need at the right time for the right cost. The need is determined by the business planning of the Company and the schedules for technology development, marketing, and related activities. The timing is developed in parallel with this scheduling element and accommodates typical development time as well as market penetration 
rates for the industry. Managing cost is a strong priority for the Company. As a bootstrapped organization founded with an initial investment of only $\$ 100$, each dollar is spent judiciously. Hiring always begins on a contract basis, allowing a trial period for both the Company and the new employee. Using this approach, Affiliate Classroom has several employees to date.

University-based hiring plays a critical role as well. Hiring university students provides a costefficient means of bringing high energy, skilled labor to Affiliate Classroom. Student-owned companies are uniquely position to leverage this talented labor pool.

\subsubsection{Training}

Barringer, Jones, and Neubaum (2005) found that rapid-growth firms depend heavily on the abilities and efforts of employees for firm growth. Firms in their study discussed the role of employee-training programs in improving employee effectiveness.

Affiliate Classroom's employee development is based on learning on the job in lieu of a formal training program. Selective hiring is used to bring employees to the Company with preexisting skills. Industry and customer knowledge is supplemented through review of Company literature and select industry magazines. While training exists, it is rudimentary in its current format.

\section{Fundamental Gaps for Aspiring Student Entrepreneurs}

In summary, these findings provide a comprehensive list of the key success factors for Affiliate Classroom. These factors have enabled Affiliate Classroom to launch the venture and manage it successfully to revenues measured in millions of dollars. In this section, a gap analysis is used to identify the factors that deserve attention from undergraduate entrepreneurship educators. The paper concludes with a discussion of the implications for entrepreneurship educators.

Undergraduate aspiring entrepreneurs may engage in a host of activities to foster their entrepreneurship education. These include courses, clubs, internships, and competitions. Anik's experiences in the Hinman CEOs Program are also considered in this study. A mapping of the impact of these activities on Anik's entrepreneurial experience is illustrated in Table 5. 
Table 5. Gap analysis for aspiring undergraduate entrepreneurs

\begin{tabular}{|c|c|c|c|c|c|}
\hline & Courses & Clubs & Internships & Competitions & Hinman $C E O s$ \\
\hline \multicolumn{6}{|l|}{ Founder characteristics } \\
\hline Education & $x$ & & & & $x$ \\
\hline Industry experience & & & $x$ & & $x$ \\
\hline Social capital & $x$ & $x$ & $x$ & $x$ & $x$ \\
\hline Passion & & & & & $x$ \\
\hline Confidence & & & $x$ & & $x$ \\
\hline \multicolumn{6}{|l|}{ Firm attributes } \\
\hline Vision for growth & $x$ & & & $x$ & $x$ \\
\hline Commitment to growth & & & & & $x$ \\
\hline Planning & $x$ & & & & $x$ \\
\hline \multicolumn{6}{|l|}{ Business practices } \\
\hline Unique value & $x$ & & $x$ & $x$ & $x$ \\
\hline Customer knowledge & $x$ & & $x$ & & $x$ \\
\hline Innovation & $x$ & & & & $x$ \\
\hline \multicolumn{6}{|c|}{ Human resources management } \\
\hline Financial incentives & $x$ & & & & $x$ \\
\hline Selective hiring & $x$ & & & & \\
\hline
\end{tabular}

\subsection{Founder characteristics}

Anik's education within courses, and social capital fostered through courses, clubs, internships, competitions, and the Hinman CEOs Program, fostered strong founder characteristics.

Students accepted into the Hinman CEOs Program engage in a community of living and learning entrepreneurship. There are four courses totaling nine credits that Hinman CEOs complete over two years. These are "ENES 460 - Fundamentals of Start-Up Ventures" and ENES 498 "Special Topics in Entrepreneurship", a repeatable speaker and case series taken each semester after the initial semester in the program. The speakers play a pivotal role in fostering student confidence, as do Hinman CEOs Program staff and students.

Industry experience for Anik was developed through his own initiative in learning about affiliate marketing. This experience pre-dated Anik's enrollment at the University of Maryland. By pairing Anik with a mentor in the online marketing arena, Anik was able to further refine his strategy and operations within the Hinman CEOs Program.

Anik's passion is an asset that he brought into the Hinman CEOs Program as well. The need for achievement, desire for personal responsibility, risk acceptance, and excitement for Affiliate Classroom's potential, while nurtured through the Hinman CEOs Program, were already germinating within Anik.

By supporting Anik's product development, business planning, and sales growth through weekly meetings and ongoing coaching, the Hinman CEOs Program incubated Affiliate Classroom through its developmental phases. 
With admittance into the VentureAccelerator program in December 2005, Anik is extending his social capital. VentureAccelerator is an MTECH Ventures program open to University of Maryland faculty and students. VentureAccelerator guides the commercialization of intellectual property created at the University of Maryland through new venture creation. VentureAccelerator is a selective program designed to assist faculty and students truly committed to the hard work of creating new companies based on innovative intellectual property. Once accepted, VentureAccelerator companies receive intense, hands-on assistance with a range of new business processes, including market validation, business planning, staffing, and initial funding through grants or equity investment.

Introductions to key industry and funding contacts are a focus of VentureAccelerator. The staff draws upon a range of personal and university relationships to enable customer, teambuilding, investor, and strategic partner introductions. On behalf of its portfolio companies, VentureAccelerator maintains close working relationships with the region's venture investors and service providers, as well as key technology companies nationwide.

\subsection{Firm attributes}

The firm attributes of vision, commitment, and planning are well served in Anik's entrepreneurship courses within the Hinman CEOs Program. Insights and direction from the University's annual Technology Start-Up Boot Camp and the annual University of Maryland \$50K Business Plan Competition further cultivated Affiliate Classroom’s firm-level attributes.

The Hinman CEOs Program manages the University's annual Technology Start-Up Boot Camp. This day-long workshop is designed to teach faculty and students how to start their own companies. The Boot Camp is taught by venture capitalists, intellectual property attorneys, marketing experts, and entrepreneurs. The Boot Camp helps faculty and students transfer innovative research and ideas out of the University setting and into the commercial sector.

The Hinman CEOs Program also manages the annual University of Maryland $\$ 50 \mathrm{~K}$ Business Plan Competition. Goals for the competition include providing education and networking opportunities for students, fostering new venture ideas and providing new opportunities for University of Maryland students and young alumni to launch ventures.

\subsection{Business practices}

The principles of unique value and customer knowledge are well instructed the University of Maryland in the courses, internships, and Hinman CEOs Program.

Developing an awareness and appreciation for innovation is an area deserving focus. The concept of innovation drives students to think in bigger and better ways, specifically when it comes to making radical improvements in the world. Innovation can set the stage for new product developments that break current markets and birth new ones. 
Fostering innovation is a core focus of the Hinman CEOs Program. By engaging students in thoughtful dialogue with accomplished entrepreneurs, university technologists, and talented venture capitalists, the seeds of innovation are sown.

\subsection{Human resource management}

While the financial incentives are discussed in courses and within the Hinman CEOs Program, Anik feels that more attention should be placed on hiring procedures and practices.

Within the Hinman CEOs Program, Anik benefited from friends and teammates living together. The lectures and weekly speaker series further provides networking opportunities as students meet leaders from the new venture community. Beyond this close knit university community, however, is the "real world", where human resources management takes a more central role in how to hire, train, and motivate professionals.

\section{Implications, Observations, and Conclusions}

The results of the paper provide several important implications for undergraduate entrepreneurship educators. First, aspiring and active undergraduate entrepreneurs benefit from education, industry experience, and social capital in a similar way to adult entrepreneurs. Beyond these similarities, it is important to understand that these positive entrepreneurship education experiences also cultivate students' passions for their ideas and for entrepreneurship. Fostering confidence is of particularly high value to students who may not have the support of friends or family in pursuing a career as an entrepreneur.

A second important implication of the study is that cultivating a commitment to growth may be lacking in existing entrepreneurship coursework and programs. While students may be encouraged to develop and plan for a bold vision, the processes to establish and maintain commitment are lacking. Discussions on goal setting and performance measurement at the tactical and strategic levels may assist in developing a commitment to growth.

A third implication of the study is that delivering unique value founded on customer understanding and company innovations play a pivotal role in new student ventures. Competitions and internships are strong contributors to this area.

The final implication of the study is that thoughtful human resources management is important to the selecting, hiring, training, and motivating of staff. The position of a young entrepreneur as a CEO is challenging, particularly when hiring experienced senior staff.

While a limitation of this study is the ability to generalize one student's experience to a broader set of students, the Hinman CEOs Program will continue to measure Anik's progress and analyze the experience of students and alumni of the Program. 


\section{References}

Barbe, D.F., Green, J.V., and Thornton, K.S. (2005, June). Student perspectives on the Hinman CEOs Program. Proceedings of the American Society for Engineering Education Annual Conference and Exposition, Portland, OR.

Barbe, D.F., and Thornton, K. S. (2002, June). Components of a comprehensive engineering entrepreneurship program. Proceedings of the American Society for Engineering Education Annual Conference and Exposition, Montreal, Canada.

Barbe, D.F., and Thornton, K.S. (2001, June). Campus entrepreneurship opportunities. Proceedings of the American Society for Engineering Education Annual Conference and Exposition, Albuquerque, NM.

Barkman, R.. (1994). Entrepreneurial characteristics and the size of the new firm: a model and an econometric test. Small Business Economics, No. 6: 117-125.

Baron, R. (1998). Cognitive mechanisms in entrepreneurship: Why and when entrepreneurs think differently than other people. Journal of Business Venturing, Vol. 13, No. 4: 275-294.

Barringer, B.R., Jones, F.F, and Neubaum, D.O. (2005). A quantitative content analysis of the characteristics of rapid-growth firms and their founders. Journal of Business Venturing 20 (2005) 663-687.

Block, Z. and Stumpf, S.A. (1992). Entrepreneurship education research: experience and challenge (pp. 17-42). In Sexton, D.L. and Kasarda, J.D. (Eds), The State of the Art of Entrepreneurship, PWS-Kent Publishing Company, Boston, MA.

Braggs, S.M. (1999). Managing explosive corporate growth. New York: Wiley.

Brehmer, B. (1980). In one word: not from experience. Acta Psychologica, Vol. 45: 223-241.

Chakrabarti, A.K. (1990). Scientific output of small and medium size firms in high-tech industries. IEEE Trans. Eng. Management, Vol 37, No. 1: 48-52.

Cooper, C.L. (1982). A theory of management learning: its implications for management education. In Freedman, R.D., Cooper,C.L. and Stumpf, S.A. (Eds), Management Education: Issues in Theory, Research and Practice, John Wiley \& Sons, New York, NY, pp. 45-55.

House, R.J. (1982). Experiential learning: a social learning theory analysis (pp. 23-44). In Freedman, R.D., Cooper, C.L. and Stumpf, S.A. (Eds), Management Education: Issues in Theory, Research and Practice, John Wiley \& Sons, New York, NY.

Day, D.L. (1992). Research linkages between entrepreneurship and strategic management or general management. In Sexton, D.L. and Kasarda, J.D. (Eds), The State of the Art of Entrepreneurship, PWS-Kent Publishing Company, Boston, MA, pp. 117-163.

Deeds, D.L., DeCarolis, D., and Coombs, J. (1999). Dynamic capabilities and new product development in high technology ventures: an empirical analysis of new biotechnology firms. Journal of Business Venturing, Vol. 15, No. 3: 211-229.

Doorley, T.L., and Donovan, J.M. (1999). Value-creating growth. San Francisco, Jossey-Bass.

Duchesneau, D., Gartner, W. (1990). A profile of new venture success and failure in an emerging industry. Journal of Business Venturing, Vol. 5, No. 5: 297-312.

Fesser, H.R., and Willard, G.E. (1990). Founding strategy and performance: a comparison of high and low growth high tech forms. Strategy Management Journal, Vol. 11, No. 2: 87-98.

Guth, W.D., Kumaraswamy, A. and McErlean, M. (1991). Cognition, enactment and learning in the entrepreneurial process. In Churchill, N.C. et al. (Eds), Frontiers of Entrepreneurship Research, 1991, Babson College, Wellesley, MA, pp. 242-53. 
Harrison, J., and Taylor, B. (1997). Supergrowth Companies. Oxford: Reed Educational and Professional Publishing.

Kim, W.C., and Mauborgne, R. (1997). Value innovation: the strategic logic of high growth. Harvard Business Review, Vol. 75, No. 1: 103-112.

Kolvereid, L. (1992). Growth aspirations among Norwegian entrepreneurs. Journal of Business Venturing, Vol. 7, No. 3: 209-222.

Landau, S.B., and Leventhal, G.S. (1976). A simulation study of administrators' behavior towards employees who receive job offers. Journal of Applied Social Psychology, Vol. 6: 291-306.

Leitch, C.M. and Harrison, R.T. (1993).Learning, culture and the diversifying corporation. Paper to the Third Global Entrepreneurship Research Conference, Groupe ESC, Lyon.

Levitt, B. and March, J.G. (1988). Organizational learning. Annual Review of Sociology, Vol. 14: 319-40.

Liao, J. and Welsch, H. (2005). Roles of social capital in venture creation: key dimensions and research implications. Journal of Small Business Management, Vol. 43, No. 4:345-362.

MacMillan, I.C., and Day, D.L. (1987). Corporate ventures into industrial markets: dynamics of aggressive entry. Journal of Business Venturing, Vol. 2, No. 1: 29-39.

Mitchell, R., Smith, B., Seawright, K., \& Morse, E. (2000). Cross-cultural cognitions and the venture creation process. Academy of Management Journal. Vol. 43, No.5: 974-993.

Mullins, J.W. (1996). Early growth decisions of entrepreneurs: the influence of competency and prior performance under changing market conditions. Journal of Business Venturing, Vol. 11, No. 2: 89-105.

Rich, J.T. (1999). The growth imperative. Journal of Business Strategy, Vol. 20, No. 2: 27-31.

Roure, J.B., and Keeley, R.H. (1990). Predictors of success in new technology-based ventures. Journal of Business Venturing, Vol. 5, No. 4: 201-220.

Sapienza, H., and Grimm, C. (1997). Founder characteristics, start-up process and strategy/structure variables as predictors of shortline railroad performance. Entrepreneurship Theory and Practice, Vol. 22, No. 1: 5-24.

Senge, P.M. (1990). The fifth discipline. New York: Bantam Doubleday Dell.

Singer, B. (1995). Contours of development. Journal of Business Venturing, Vol. 10, No. 4: 303329.

Slevin, D.P. and Colvin, J.G. (1992). Creating and maintaining high performance teams. In Sexton, D.L and. Kasarda, J.D (Eds), The State of the Art of Entrepreneurship, PWS-Kent Publishing Company, Boston, MA, pp. 358-86.

Sterman, J.D. (1989). Modeling managerial behavior: misperceptions of feedback in a dynamic decision making experiment. Management Science, Vol. 35: 321-39.

Trendsetter Barometer, 2000. PricewaterhouseCoopers Consulting, New York, March 13.

Vesper, K.H. \& Gartner, W.B. (1997, May). Measuring progress in entrepreneurship education. Journal of Business Venturing, Vol. 12, No. 5: 403-421.

Ward, T.B. (2004). Cognition, creativity, and entrepreneurship. Journal of Business Venturing. Vol. 19, No. 2: 173-188.

Weitzman, M., and Kruse, D.L. (1990). The effects of profit sharing on employment, wages, stock returns and productivity: evidence from UK micro-data. Economics Journal, Vol. 100, No. 399: 1-17. 
Zenger, T.R. (1992). Why do employers only reward extreme performance? Examining the relationships among performance pay and turnover. Administrative Science Quarterly, Vol. 37, No. 2: 198-219. 